\title{
Cardiac Disease in Chronic Obstructive Pulmonary Disease
}

\author{
Jeremy A. Falk1, Steven Kadiev², Gerard J. Criner ${ }^{3}$, Steven M. Scharf ${ }^{4}$, Omar A. Minai ${ }^{5}$, and Philip Diaz ${ }^{2}$ \\ ${ }^{1}$ Division of Pulmonary and Critical Care Medicine, Department of Medicine, Cedars-Sinai Medical Center, for the David Geffen School \\ of Medicine at UCLA, Los Angeles, California; ${ }^{2}$ Division of Pulmonary and Critical Care, Ohio State University Medical Center, Columbus, Ohio; \\ ${ }^{3}$ Division of Pulmonary and Critical Care Medicine, Temple Lung Center, Temple University School of Medicine, Philadelphia, Pennsylvania; \\ ${ }^{4}$ University of Maryland School of Medicine, Baltimore, Maryland; and ${ }^{5}$ Department of Pulmonary, Allergy, and Critical Care Medicine, \\ Cleveland Clinic, Cleveland, Ohio
}

\begin{abstract}
The cardiac manifestations of chronic obstructive pulmonary disease (COPD) are numerous. Impairments of right ventricular dysfunction and pulmonary vascular disease are well known to complicate the clinical course of COPD and correlate inversely with survival. The pathogenesis of pulmonary vascular disease in COPD is likely multifactorial and related to alterations in gas exchange and vascular biology, as well as structural changes of the pulmonary vasculature and mechanical factors. Several modalities currently exist for the assessment of pulmonary vascular disease in COPD, but right heart catheterization remains the gold standard. Although no specific therapy other than oxygen has been generally accepted for the treatment of pulmonary hypertension in this population, there has been renewed interest in specific pulmonary vasodilators. The coexistence of COPD and coronary artery disease occurs frequently. This association is likely related to shared risk factors as well as similar pathogenic mechanisms, such as systemic inflammation. Management strategies for the care of patients with COPD and coronary artery disease are similar to those without COPD, but care must be given to address their respiratory limitations. Arrhythmias occur frequently in patients with COPD, but are rarely fatal and can generally be treated medically. Use of $\beta$-blockers in the management of cardiac disease, while a theoretical concern in patients with increased airway resistance, is generally safe with the use of cardioselective agents.
\end{abstract}

Keywords: emphysema; pulmonary hypertension; cor pulmonale; coronary artery disease

The cardiovascular sequelae of chronic obstructive pulmonary disease (COPD) have been recognized for decades (1). The spectrum of cardiovascular disease includes right ventricular (RV) dysfunction, pulmonary hypertension $(\mathrm{PH})$, coronary artery disease (CAD), and arrhythmias (2). Pulmonary vascular disease associated with COPD increases morbidity and worsens survival $(1,3-8)$. Patients with COPD also carry an increased risk of mortality due to arrhythmia, myocardial infarction, or congestive heart failure compared with those who do not $(2,3,9)$. The Lung Health Study showed that a substantial proportion of deaths in patients with mild COPD was the result of cardiovascular complications, and a recent large epidemiologic study revealed increased cardiovascular mortality, particularly in patients younger than 65 years

(Received in original form August 29, 2007; accepted in final form November 15, 2007) Funding for the National Emphysema Treatment Trial (NETT) is supported by contracts with the National Heart, Lung, and Blood Institute (N01HR76101, N01HR76102, N01HR76103, N01HR76104, N01HR76105, N01HR76106, N01HR76107, N01HR76108, N01HR76109, N01HR76110, N01HR76111, N01HR76112, N01HR76113, N01HR76114, N01HR76115, N01HR76116, N01HR76118, and N01HR76119); the Centers for Medicare and Medicaid Services (CMS); and the Agency for Healthcare Research and Quality (AHRQ).

Correspondence and requests for reprints should be addressed to Jeremy A. Falk, M.D., 8700 Beverly Boulevard, Room 6732, Los Angeles, CA 90048. E-mail: falkja@cshs.org

Proc Am Thorac Soc Vol 5. pp 543-548, 2008

DOI: 10.1513/pats.200708-142ET

Internet address: www.atsjournals.org with COPD (10, 11). Because cardiac abnormalities clearly contribute to the overall morbidity associated with COPD, an understanding of their role and potential for treatment is vital.

\section{RIGHT VENTRICULAR DYSFUNCTION}

\section{Prevalence}

Although RV dysfunction and $\mathrm{PH}$ are common in COPD, increases in mean pulmonary artery pressures $(\overline{\mathrm{Ppa}})$ tend to be mild to moderate. In a National Emphysema Treatment Trial (NETT) substudy, $90.8 \%$ of patients with severe emphysema had an $\overline{\mathrm{Ppa}}$ greater than $20 \mathrm{~mm} \mathrm{Hg}$, and a small minority (5\%) had an $\overline{\text { Ppa }}$ greater than $35 \mathrm{~mm} \mathrm{Hg}$ (12). Similarly, among a cohort of 998 patients with COPD (median $\mathrm{FEV}_{1}=50 \%$ of predicted) only 27 (2.7\%) had secvere $\mathrm{PH}(\overline{\mathrm{Ppa}} \geqslant 40 \mathrm{~mm} \mathrm{Hg})$ (13). Interestingly, more than half of these 27 patients had non-COPD etiologies explaining their severe $\mathrm{PH}$. Previous estimates of the prevalence of PH in COPD had been 20 to $30 \%$, with some evidence that pulmonary hemodynamics worsen with worsening airflow obstruction $(1,3,14)$. Overall, current data suggest that PH occurs commonly in COPD but that it is rarely severe.

\section{Natural History}

Few studies have examined the natural history of PH in COPD. Two studies have shown an annual increase in $\overline{\mathrm{Ppa}}$ in COPD of 0.4 to $0.6 \mathrm{~mm} \mathrm{Hg}$ per year $(15,16)$. Weitzenblum and colleagues examined 93 patients with severe COPD who underwent two right heart catheterizations over a span of at least 2 years (15). Thirty-two patients had an $\overline{\mathrm{Ppa}}$ greater than $20 \mathrm{~mm} \mathrm{Hg}$ at entry. Overall, the group had an average increase in $\overline{\mathrm{Ppa}}$ of $0.6 \mathrm{~mm} \mathrm{Hg}$ per year. Kessler and colleagues examined 131 patients with moderate COPD and normal resting hemodynamics over 7 years (16). $\overline{\mathrm{Ppa}}$ increased $0.4 \mathrm{~mm} \mathrm{Hg}$ per year. Thirty-three patients (25.2\%) developed $\mathrm{PH}$ over the course of the study. Resting hypoxemia and exercise-induced $\mathrm{PH}$ were independent risk factors for the development of $\mathrm{PH}$ during follow-up. These studies illustrate that $\mathrm{PH}$ in COPD progresses slowly and occurs in milder as well as severe forms of the disease.

\section{Prognosis}

Multiple studies have now shown that the presence of $\mathrm{PH}$ in COPD has a negative impact on survival $(1,3-8)$. Data evaluating patients with COPD who have undergone right heart catheterization have consistently shown an inverse relationship between pulmonary artery pressure (Ppa) and survival $(1,3,5)$. In addition, noninvasive measures of $\mathrm{PH}$ in COPD, such as electrocardiogram, echocardiogram, and brain natriuretic peptide (BNP), have demonstrated similar finding with respect to survival (6-8).

\section{Pathogenesis}

Hypoxia. Chronic hypoxia likely plays a role in the pathogenesis of PH in COPD by inducing vascular remodeling. Hypoxic 
vasoconstriction may become increasingly significant during exercise due to decreased mixed venous partial pressure of oxygen. Hypercarbia and acidosis may also cause elevations in $\overline{\mathrm{Ppa}}$ either by amplification of hypoxic vasoconstriction or by stimulating hyperventilation $(17,18)$.

Vascular remodeling. Structural changes in the small pulmonary arteries in lungs of patients with COPD have been described (19). Both intimal and medial thickening have been described in the small pulmonary arteries of patients with COPD; however, intimal thickening with components of cellular hypertrophy and hyperplasia have been the most consistently demonstrated morphologic features $(19,20)$. Similar features have been observed in pulmonary arteries in chronic hypoxemia. However, hypoxemia alone cannot account for all of these changes, because intimal thickening is observed in mild COPD, as well as in smokers without obstruction and with normal arterial oxygenation (21, 22). It is also clear that morphologic changes in the pulmonary vascular bed are not solely responsible for the development of $\mathrm{PH}$, because the correlations between Ppa at rest and morphometry are weak $(19,23,24)$.

Pulmonary artery endothelial dysfunction occurs in PH. For example, abnormal vascular ring relaxation in vitro inversely correlates with the degree of intimal thickening $(25,26)$. Mediators important in pulmonary artery vasodilation, including nitric oxide synthase and prostacyclin synthase, are deficient in the COPD pulmonary vascular bed (26-28). Endothelin-1, a potent pulmonary artery vasoconstrictor, occurs in higher concentrations in the tissue and serum of patients with COPD compared with normal subjects (29). Vascular endothelial growth factor is increased in COPD lung tissue, and its level correlates with the degree of intimal thickening $(30,31)$. Serotonin has also been implicated in the pathogenesis of pulmonary vascular remodeling in COPD because polymorphisms of the serotonin transporter (5-HTT) gene seem to correlate with the severity of PH (32). Several studies now document the local role that inflammation plays in the COPD pulmonary vascular disease. Increases in vascular wall inflammatory cells are correlated with pulmonary arterial wall thickness as well as with abnormal vascular relaxation $(33,34)$.

Elastic recoil. It has been proposed that, in emphysema, loss of tethering effect from reduced lung elastic recoil is partly responsible for the development of PH and subsequent RV dysfunction. For example, Sciurba and coworkers noted an improvement in RV function after lung volume reduction surgery (LVRS) associated with increased elastic recoil (35). However, a larger study failed to demonstrate a correlation between elastic recoil and Ppa in patients being evaluated for LVRS as part of NETT (36). In addition, compared with medical therapy (37), significant changes in pulmonary hemodynamics after LVRS have not been observed.

Dynamic hyperinflation. Dynamic hyperinflation is a wellknown consequence of severe emphysema. Gas trapping during exercise may lead to dynamic compression of the pulmonary arteries. In a study of 17 patients with COPD undergoing lung resection, none of whom had abnormal resting hemodynamics, those with severe small airway disease and emphysema developed exercise-induced PH (38).

\section{Assessment}

Echocardiogram. Echocardiography is an attractive method for measuring right-sided pressures in patients and has been used as a screening tool for PH; however, the accuracy of echocardiography for assessing of pulmonary hemodynamics in COPD has recently been called into question (39-41). In 374 patients being evaluated for lung transplant, an estimate of pulmonary artery systolic pressure was possible in only $38 \%$ of the patients with
COPD. Furthermore, accuracy was only $56 \%$ compared with right heart catheterization (42). In 63 NETT patients, Fisher and coworkers compared echocardiographic and right heart catheterization measures of Ppa (43). They found little correlation between the paired measures of Ppa. Compared with invasive measures, echocardiography had a sensitivity of $60 \%$ and a specificity of $74 \%$. Thus, echocardiography cannot be recommended as a substitute for pulmonary artery catheterization in patients with emphysema.

Pulmonary artery catheterization. Right heart catheterization is considered the gold standard in the assessment of pulmonary hemodynamics. Although right heart catheterization is believed to provide the most accurate assessment of right-sided pressures, interpretation of pressure waveforms in patients with severe emphysema can be complicated by significant swings in pleural pressures due to hyperinflation and gas trapping in overly compliant lungs. Its invasive nature also precludes its routine use in the evaluation of COPD. Its use is reasonable, however, in patients in whom significant elevations are suspected or in patients being evaluated for potential LVRS or transplant.

$B N P$. BNP is now widely accepted as a diagnostic tool in the management of left ventricular dysfunction $(44,45)$. The role of BNP in the assessment of RV dysfunction, particularly in the setting of chronic lung disease, is less clear. A recent study of patients with chronic lung disease showed BNP to be elevated in patients with significant $\mathrm{PH}$ and was a predictor of death (8). This study was underrepresented in patients with both significant PH and COPD; however, the use of BNP as a biomarker of $\mathrm{RV}$ dysfunction in patients with chronic lung disease appears promising.

\section{Treatment}

Oxygen therapy. Long-term oxygen is the sole pharmacologic treatment that has been shown to improve survival in patients with COPD with severe hypoxemia $(46,47)$. Although longterm oxygen has been shown to limit the progression of $\mathrm{PH}$ in hypoxemic patients with COPD, survival benefits have not been linked to any hemodynamic improvements (15).

Vasodilators. Several selective pulmonary artery vasodilators are available for the treatment of $\mathrm{PH}$. A theoretical concern of vasodilators in COPD is worsening gas exchange by impairing ventilation-perfusion matching (48-50). Roger and colleagues administered inhaled nitric oxide to nine patients with COPD at rest and during exercise with a pulmonary artery catheter in place (50). Although there was a significant decrease in Ppa at rest, there was also a significant drop in $\mathrm{Pa}_{\mathrm{O}_{2}}$. During exercise, improvements were observed in $\overline{\mathrm{Ppa}}$; however, $\mathrm{Pa}_{\mathrm{O}_{2}}$ remained relatively constant, suggesting pulmonary blood flow redistribution to alveolar units with better ventilation. Intravenous prostacyclin has been used during acute COPD exacerbations in patients with $\overline{\mathrm{Ppa}}$ greater than $30 \mathrm{~mm} \mathrm{Hg}$ (48). Although a decrease in $\overline{\mathrm{Ppa}}$ was observed, $\mathrm{Pa}_{\mathrm{O}_{2}}$ was significantly decreased from baseline. More recently, Vonbank and colleagues randomized 40 patients with severe COPD to receive pulsed doses of inhaled nitric oxide and oxygen or placebo and oxygen over 3 months (49). Patients randomized to the nitric oxide group showed improvements in $\overline{\mathrm{Ppa}}$, pulmonary vascular resistance, and cardiac output without any worsening in systemic oxygenation.

Diuretics. Peripheral edema in patients with COPD with RV dysfunction can be treated with diuretics. Care must be given in administering diuretics to this patient population, however, as increased RV afterload frequently requires higher filling pressures to maintain cardiac output. In addition, overuse of diuretics, particularly loop diuretics, may lead to metabolic derangements, such as metabolic alkalosis (51). 
LVRS. Contradictory information exists regarding the development of PH after LVRS. Weg and coworkers reported an elevation in Ppa after surgery in nine LVRS patients (52). Other studies have not duplicated this finding and some suggest an improvement in pulmonary hemodynamics $(35,53,54)$. Differences in the findings between these studies likely may relate to differences in patient selection, baseline lung function, and anatomic distribution of emphysema. Recent data from the NETT, which represents the largest prospective investigation of the effects of LVRS on pulmonary hemodynamics in patients with moderate to severe emphysema, showed no significant changes with LVRS (37). The NETT study did demonstrate, however, that, compared with baseline, post-LVRS improvements in $\mathrm{Pa}_{\mathrm{O}_{2}}$ were correlated directly with improvement in RV ejection fraction and inversely with reduction in pulmonary wedge pressure. In addition, change in $\overline{\mathrm{Ppa}}$ was inversely correlated with change in $\mathrm{FEV}_{1}$, whereas improvement in exercise capacity was significantly associated with decreased Ppa.

\section{CORONARY ARTERY DISEASE}

\section{Prevalence}

Patients with COPD are also at increased risk for CAD and other smoking-related illnesses. In a recent large cohort of nearly 400,000 veterans with COPD admitted to a Veterans Administration (VA) hospital or VA clinic, the prevalence of CAD was $33.6 \%$, significantly higher than the $27.1 \%$ prevalence seen in a matched cohort without COPD (55). Others have also confirmed a high prevalence of CAD in COPD $(11,56-59)$.

\section{Pathogenesis}

Various studies have reported a strong link between the occurrence of COPD and the presence of CAD. The causal link between these diseases has historically been cigarette smoking, but the exact mechanisms have only recently been studied. Epidemiologic evidence supports the importance of systemic inflammation in the pathogenesis of atheroma formation and ischemic heart disease, and recent studies have indicated that patients with COPD have a prominent systemic inflammatory response (57, 59-64). C-reactive protein (CRP), a known marker of systemic inflammation (65), for example, has been shown to be elevated in patients with both stable COPD and during exacerbation (66-69). Because elevations in CRP have been linked to CAD (70), it appears as though the pathogenesis of both COPD and CAD may stem from enhanced systemic inflammation. Although data supporting the use of statin therapy for primary prevention of CAD are currently lacking, there are data showing that the use of statins reduces systemic inflammation as evidenced by reductions in CRP (71-74). In addition, the observation that the use of statin therapy is associated with a significant reduction in respiratoryrelated mortality after a COPD exacerbation further underscores the likely importance of inflammation in this disease (75).

\section{Assessment}

Noninvasive assessment of coronary disease in COPD is problematic because patients with COPD are often ventilatory limited in exercise, and pharmacologic stress testing (including adenosine and dipyrimadole) may be associated with bronchospasm (76, 77). Although a rigorous nurse-directed protocol may allow dipyrimadole testing to be done safely in some patients with COPD, it is not recommended in severe disease (77).

Although recent data highlight the safety of dobutamine echocardiography in the general patient population, its safety and efficacy in COPD is not known $(78,79)$. Hyperinflation accompanying COPD may limit the diagnostic accuracy of trans- thoracic echocardiography for detecting wall motion abnormalities with stress.

Recent data indicate that noninvasive 64-slice multidetector computed tomography (64-MDCT) coronary angiography has comparable diagnostic accuracy to traditional invasive quantitative coronary angiography (80). However, its utility for assessing $\mathrm{CAD}$ in COPD has not been determined. Given the increasing recognition of the potential importance of $\mathrm{CAD}$ to the natural history of COPD, development of noninvasive techniques to assess coronary disease in this population is required.

\section{Treatment}

Although $\beta$-blockade plays a pivotal role in the management of $\mathrm{CAD}$, there has been longstanding concern that it may precipitate bronchospasm in COPD. However, the use of cardioselective $\beta$-blockers such as atenolol and metoprolol, appears to be safe. Camsari and colleagues examined the use of metoprolol in 50 patients with COPD (mean $\mathrm{FEV}_{1}, 50 \%$ of predicted) and found no adverse effects (81). Two recent meta-analyses examining single-dose as well as chronic $\beta$-blocker treatment in patients with reactive airway disease and COPD demonstrated no evidence of adverse respiratory effects $(82,83)$. In addition to their role in CAD, the use of $\beta$-blockers has become standard of care for most patients with left ventricular dysfunction (84). Although most studies examining the use of $\beta$-blockers in heart failure have excluded patients with COPD, available evidence has shown that the use of nonselective $\alpha$ - and $\beta$-blockers such as carvedilol is safe in these patients, although caution should be used in patients with reversible airflow obstruction as in asthma (85-88). Given the demonstrated efficacy of these agents in CAD and heart failure, existing data suggest that these agents should not be routinely withheld in patients with concomitant COPD (89).

Limited data exist regarding the safety and efficacy of coronary revascularization in COPD. Prospectively collected data on 183 patients with COPD undergoing percutaneous coronary intervention revealed no increase in in-hospital adverse cardiac outcomes; however, patients with COPD had increased long-term mortality when compared with those without COPD (90). Likewise, surgical revascularization can be performed safely in patients with CAD and concomitant COPD, although long-term survival in patients with COPD is significantly reduced (91). Zhu and colleagues performed a retrospective analysis comparing conventional coronary artery bypass grafting (CABG) with off-pump CABG in COPD, and found fewer postoperative respiratory complications and a higher $\mathrm{Pa}_{\mathrm{O}_{2}} / \mathrm{FI}_{\mathrm{O}_{2}}$ ratio with off-pump CABG (92).

\section{CARDIAC DYSRHYTHMIAS}

\section{General}

COPD increases the risk of cardiac dysrhythmias. Although the risk is clearly elevated during an acute exacerbation or thoracic surgery, a fairly high rate of rhythm disturbances exists in patients with COPD even while stable. The pathogenesis of dysrhythmias in COPD is likely multifactorial and includes a number of risk factors such as hypoxemia, acidosis, and reduced $\mathrm{FEV}_{1}$ (93). Multifocal atrial tachycardia (MAT) is often found in COPD and has been frequently described during times of exacerbation $(94,95)$ This is important to recognize, because patients with COPD and MAT have a high mortality rate (94).

\section{Treatment}

The general approach to treating dysrhythmias in COPD is similar to that used in the general population. However, there are a number of special considerations in COPD. Supraventricular tachyarrhythmias (SVTs) are common after CABG in 
COPD (96). Although these rhythms are often benign in the nonCOPD patient, in COPD, these SVTs (commonly atrial fibrillation and MAT) may persist for a long period of time and cause hypotension, systemic embolization, congestive heart failure, and anxiety and may lengthen the postoperative hospitalization period (96). A recent randomized controlled trial has demonstrated that post-CABG amiodarone prophylaxis in patients with COPD significantly reduces the incidence of SVT, MAT, as well as hospital and ICU-related length of stay (96).

The treatment of MAT focuses primarily on managing the precipitating cause of the rhythm disturbance. MAT is not amenable to cardioversion and can be successfully rate controlled with $\beta$-blockers or diltiazem (94). Other options include amiodarone and high-dose magnesium (94). Medically refractory MAT has been successfully treated with catheter-directed radiofrequency ablation, which may improve quality of life and left ventricular function in selected patients. Furthermore, this approach appears to be cost-effective and consumes fewer health care resources (97).

\section{Respiratory Treatment and Dysrhythmias}

$\boldsymbol{\beta}_{2}$-Agonists. The relationship between $\beta$-agonist use and cardiovascular complications is controversial. Salpeter and colleagues recently published a meta-analysis of 18 randomized trials involving $\beta_{2}$-agonist use in COPD (98). The majority of the trials examined the use of long-acting $\beta_{2}$-agonists. The authors found an increased incidence of tachycardia and hypokalemia among subjects taking $\beta_{2}$-agonists and hypothesized that these abnormalities could contribute to an increase in cardiovascular deaths among $\beta_{2}$-agonist users (98). Nevertheless, this speculation has been largely refuted by the recently published TORCH (TOwards a Revolution in COPD Health) study, in which more than 6,000 patients with COPD were randomized to salmeterol, fluticasone, combination salmeterol-fluticasone, or placebo (99). Overall mortality, cardiovascular mortality, and cardiovascularrelated adverse events were no greater in the salmeterol group compared with any of the other groups.

Oral corticosteroids. A relationship has been reported between high-dose corticosteroid $(>7.5 \mathrm{mg} / \mathrm{d}$ prednisone or equivalent) and development of atrial fibrillation. The risk of new-onset atrial fibrillation was significantly higher in those who received a corticosteroid prescription within the preceding month and was independent of the indication for prescription (100). A similar relationship was reported with using corticosteroids and the onset of atrial fibrillation and ventricular arrhythmias. Of note, this study showed no increased arrhythmogenicity of inhaled corticosteroids (101). The etiology of arrhythmias associated with the use of systemic steroids is unknown, but several mechanisms have been proposed, including local potassium efflux, mineralocorticoid effect leading to hypertension, development of late potentials, vasodilation, and possible anaphylaxis (102-105).

Theophylline. Theophylline can predispose to tachyarrythmias even in the absence of elevated serum drug levels. For example, short-term use of theophylline is associated with increased arrhythmias, in particular atrial fibrillation (101).

\section{CONCLUSIONS}

The spectrum of cardiovascular complications associated with COPD is clearly broad. RV dysfunction and pulmonary vascular disease are common in COPD and progress with time, although their clinical significance is unclear. Although patients with COPD with $\mathrm{PH}$ appear to have increased mortality, specific therapies aimed at ameliorating pulmonary vascular disease in this patient population have been met with mixed results. Other cardiac diseases found frequently in patients with COPD, including $\mathrm{CAD}$ and arrhythmias, present a unique challenge for clinicians, as the combination of both pulmonary and cardiac disease appears to be additive with regard to morbidity and mortality.

Conflict of Interest Statement: None of the authors has a financial relationship with a commercial entity that has an interest in the subject of this manuscript.

\section{References}

1. Burrows B, Kettel LJ, Niden AH, Rabinowitz M, Diener CF. Patterns of cardiovascular dysfunction in chronic obstructive lung disease. N Engl J Med 1972;286:912-918.

2. Hunninghake D. Cardiovascular disease in chronic obstructive pulmonary disease. Proc Am Thorac Soc 2005;2:44-49.

3. Weitzenblum E, Hirth C, Ducolone A, Mirhom R, Rasaholinjanahary J, Ehrhart M. Prognostic value of pulmonary artery pressure in chronic obstructive pulmonary disease. Thorax 1981;36:752-758.

4. Traver GA, Cline MG, Burrows B. Predictors of mortality in chronic obstructive pulmonary disease: a 15-year follow-up study. Am Rev Respir Dis 1979;119:895-902.

5. Oswald-Mammosser M, Weitzenblum E, Quoix E, Chaouat A, Charpentier C, Kessler R. Prognostic factors in COPD patients receiving long-term oxygen therapy: importance of pulmonary artery pressure. Chest 1995;107:1193-1198.

6. Burgess MI, Mogulkoc N, Bright-Thomas RJ, Bishop P, Egan JJ, Ray SG. Comparison of echocardiographic markers of right ventricular function in determining prognosis in chronic pulmonary disease. $\mathrm{J} \mathrm{Am}$ Soc Echocardiogr 2002;15:633-639.

7. Incalzi RA, Fuso L, De Rosa M, Di Napoli A, Basso S, Pagliari G, Pistelli R. Electrocardiographic signs of chronic cor pulmonale: a negative prognostic finding in chronic obstructive pulmonary disease. Circulation 1999;99:1600-1605.

8. Leuchte HH, Baumgartner RA, Nounou ME, Vogeser M, Neurohr C, Trautnitz M, Behr J. Brain natriuretic peptide is a prognostic parameter in chronic lung disease. Am J Respir Crit Care Med 2006;173:744-750.

9. Cooper R, Ghali J, Simmons BE, Castaner A. Elevated pulmonary artery pressure: an independent predictor of mortality. Chest 1991;99:112-120.

10. Lung Health Study Research Group. Effect of inhaled triamcinolone on the decline in pulmonary function in chronic obstructive pulmonary disease. N Engl J Med 2000;343:1902-1909.

11. Sidney S, Sorel M, Quesenberry CP, DeLuise C, Lanes S, Eisner MD. COPD and incident cardiovascular disease hospitalizations and mortality: Kaiser Permanente Medical Care Program. Chest 2005;128: 2068-2075.

12. Scharf S, Iqbal M, Kellar C, Criner G, Lee S, Fessler H. Hemodynamic characterization of patients with severe emphysema. Am J Respir Crit Care Med 2002;166:314-322.

13. Chaouat A, Bugnet A, Kadaoui N, Schott R, Enache I, Ducolone A, Ehrhart M, Kessler R, Weitzenblum E. Severe pulmonary hypertension and chronic obstructive pulmonary disease. Am J Respir Crit Care Med 2005;172:189-194.

14. Weitzenblum E, Sautegeau A, Ehrhart M, Mammosser M, Hirth C, Roegel E. Long-term course of pulmonary arterial pressure in chronic obstructive pulmonary disease. Am Rev Respir Dis 1984;130:993-998.

15. Weitzenblum E, Sautegeau A, Ehrhart M, Mammosser M, Pelletier A. Long-term oxygen therapy can reverse the progression of pulmonary hypertension in patients with chronic obstructive pulmonary disease. Am Rev Respir Dis 1985;131:493-498.

16. Kessler R, Faller M, Weitzenblum E, Chaouat A, Aykut A, Ducoloné A, Ehrhart M, Oswald-Mammosser M. "Natural history" of pulmonary hypertension in a series of 131 patients with chronic obstructive pulmonary disease. Am J Respir Crit Care Med 2001;164:219-224.

17. Enson Y, Guintini C, Lewis ML, Morris TQ, Ferrer MI, Harvey RM. The influence of hydrogen ion concentration and hypoxia on the pulmonary circulation. J Clin Invest 1964;43:1146-1162.

18. Durand J, Leroy-Ladurie M, Ransom-Bitker B. Effects of hypoxia and hypercapnia on the repartition of pulmonary blood flow in supine subjects. Respir Res 1970;5:156-165.

19. Wright JL, Petty T, Thurlbeck WM. Analysis of the structure of the muscular pulmonary arteries in patients with pulmonary hypertension and COPD: National Institutes of Health Nocturnal Oxygen Therapy Trial. Lung 1992;170:109-124.

20. Hale KA, Niewoehner DE, Cosio MG. Morphologic changes in the muscular pulmonary arteries: relationship to cigarette smoking, airway disease, and emphysema. Am Rev Respir Dis 1980;122:273-278. 
21. Peinado V, Barbera J, Ramirez J, Gomez FP, Roca J, Jover L, Gimferrer JM, Rodriguez-Roisin R. Endothelial dysfunction in pulmonary arteries of patients with mild COPD. Am J Physiol Lung Cell Mol Physiol 1998;274:908-913.

22. Barbera JA, Riverola A, Roca J, Ramirez J, Wagner PD, Ros D, Wiggs BR, Rodriguez-Roisin R. Pulmonary vascular abnormalities and ventilation-perfusion relationships in mild chronic obstructive pulmonary disease. Am J Respir Crit Care Med 1994;149:423-429.

23. Falk JA, Abdallah HY, Solomides CC, Criner GJ. Association of pulmonary artery wall hypertrophy with pulmonary hemodynamics in severe emphysema: a morphometric study [abstract]. Am J Respir Crit Care Med 2004;169:A616.

24. Falk JA, Grookett TW, Abdallah HY, Gaughan JP, Solomides CC, Criner GJ. Morphometric analysis of small pulmonary arteries in severe emphysema [abstract]. Proc Am Thorac Soc 2005;2:A140.

25. Dinh-Xuan A, Higenbottom T, Clelland C, Pepke-Zaba J, Cremona G, Butt AY, Large SR, Wells FC, Wallwork J. Impairment of endothelium-dependent pulmonary artery relaxation in chronic obstructive lung disease. $N$ Engl J Med 1991;324:1539-1547.

26. Giaid A, Saleh D. Reduced expression of endothelial nitric oxide synthase in the lungs of patients with pulmonary hypertension. $N$ Engl J Med 1995;333:214-221.

27. Barbera J, Peinado V, Santos S, Ramires J, Roca J, d'Rodriguez-Rosin R. Reduced expression of endothelial nitric oxide synthase in pulmonary arteries of smokers. Am J Respir Crit Care Med 2001;164:709-713.

28. Lee J, Tarasevicience-Stewart L, Keith R, Geraci M, Voelkel N. The expression of prostacyclin synthase is decreased in the small pulmonary arteries of patients with emphysema. Chest 2005;128:575S.

29. Celik G, Karabiyikoğlu G. Local and peripheral plasma endothelin-1 in pulmonary hypertension secondary to chronic obstructive pulmonary disease. Respiration 1998;65:289-294.

30. Voelkel N, Cool C. Pulmonary vascular involvement in chronic obstructive pulmonary disease. Eur Respir J 2003;46:28s-32s.

31. Santos S, Peinado VI, Ramirez J, Morales-Blanhir J, Bastos R, Roca J, Rodriguez-Roisin R, Barbera JA. Enhanced expression of vascular endothelial growth factor in pulmonary arteries of smokers and patients with moderate chronic obstructive pulmonary disease. $\mathrm{Am}$ J Respir Crit Care Med 2003;167:1250-1256.

32. Eddahibi S, Chaouat A, Morrell N, Fadel E, Fuhrman C, Bugnet AS, Dartevelle P, Housset B, Hamon M, Weitzenblum E, et al. Polymorphism of the serotonin transporter gene and pulmonary hypertension in chronic obstructive pulmonary disease. Circulation 2003; 108:1839-1844.

33. Peinado V, Barbera J, Abate P, Ramirez J, Roca J, Santos S, Rodriguez $\mathrm{R}$. Inflammatory reaction in pulmonary muscular arteries of patients with chronic obstructive pulmonary disease. Am J Respir Crit Care Med 1999;159:1605-1611.

34. Saetta M, Baraldo S, Corbino L, Turato G, Braccioni F, Rea F, Cavallesco G, Tropeano G, Mapp CE, Maestrelli P, et al. CD8+ve cells in the lungs of smokers with chronic obstructive pulmonary diesase. Am J Respir Crit Care Med 1999;160:711-717.

35. Sciurba FC, Rogers RM, Keenan RJ, Slivka WA, Gorcsan J, Ferson $\mathrm{PF}$, Holbert JM, Brown ML, Landreneau RJ. Improvement in pulmonary function and elastic recoil after lung-reduction surgery for diffuse emphysema. $N$ Engl J Med 1996;334:1095-1099.

36. Falk JA, Martin UJ, Scharf SM, Criner GJ. Lung elastic recoil does not correlate with pulmonary hemodynamics in severe emphysema. Chest 2007;132:1476-1484.

37. Criner GJ, Scharf SM, Falk JA, Gaughan JP, Sternberg AL, Patel NB, Fessler HE, Minai OA, Fishman AP. Effect of lung volume reduction surgery on resting pulmonary hemodynamics in severe emphysema. Am J Respir Crit Care Med 2007;176:253-260.

38. Wright JL, Lawson L, Pare PD, Hooper RO, Peretz DI, Nelems JM, Schulzer M, Hogg JC. The structure and function of the pulmonary vasculature in mild chronic obstructive pulmonary disease: the effect of oxygen and exercise. Am Rev Respir Dis 1983;128:702-707.

39. Currie PJ, Seward JB, Chan K-L, Fyfe DA, Hagler DJ, Mair DD, Reeder GS, Nishimura RA, Tajik AJ. Continuous wave Doppler estimation of right ventricular pressure: a simultaneous Doppler-catheterization study in 127 patients. J Am Coll Cardiol 1985;6:750-756.

40. Yock PG, Popp RL. Noninvasive estimation of right ventricular systolic pressure by Doppler ultrasound in patients with tricuspid regurgitation. Circulation 1984;70:657-662.

41. Chan K-L, Currie PJ, Seward JB, Hagler DJ, Mair DD, Tajik AJ. Comparison of three Doppler ultrasound methods in the prediction of pulmonary artery pressure. J Am Coll Cardiol 1987;9:549-554.
42. Arcasoy SM, Christie JD, Ferrari VA, Sutton MS, Zisman DA, Blumenthal NP, Pochettino A, Kotloff RM. Echocardiographic assessment of pulmonary hypertension in patients with advanced lung disease. Am J Respir Crit Care Med 2003;167:735-740.

43. Fisher MR, Criner GJ, Fishman AP, Hassoun PM, Minai O, Scharf SM, Fessler HE. Estimating pulmonary artery pressure by echocardiography in patients with emphysema. Eur Respir J 2007;30:914-921.

44. Richards AM, Nicholls MG, Espiner EA, Lainchbury JG, Troughton RW, Elliott J, Frampton C, Turner J, Crozier IG, Yandle TG. B-type natriuretic peptides and ejection fraction for prognosis after myocardial infarction. Circulation 2003;107:2786.

45. Kruger S, Graf J, Kunz D, Stickel T, Hanrath P, Janssens U. Brain natriuretic peptide levels predict functional capacity in patients with chronic heart failure. J Am Coll Cardiol 2002;40:718-722.

46. Medical Research Council Working Party. Long term domiciliary oxygen therapy in chronic hypoxic cor pulmonale complicating chronic bronchitis and emphysema. Lancet 1981;1:681-686.

47. Nocturnal Oxygen Therapy Trial Group. Continuous or nocturnal oxygen therapy in hypoxemic chronic obstructive lung disease: a clinical trial. Ann Intern Med 1980;93:391-398.

48. Archer S, Mike D, Crow J, Long W, Weir E. A placebo controlled trial of prostacyclin in acute respiratory failure in COPD. Chest 1996;109: $750-755$.

49. Vonbank K, Ziesche R, Higenbottam T, Stiebellehner L, Petkov V, Schenk P, Germann P, Block LH. Controlled prospective randomized trial on the effects on pulmonary haemodynamics of the ambulatory long term use of nitric oxide and oxygen in patients with severe COPD. Thorax 2003;58:289-293.

50. Roger N, Barbera J, Roca J, Rovira I, Gomez F, Rodriguez-Roisin R. Nitric oxide inhalation during exercise in chronic obstructive pulmonary disease. Am J Respir Crit Care Med 1997;156:800-806.

51. Brijker F, Heijdra YF, van den Elshout FJ, Folgering HT. Discontinuation of furosemide decreases $\mathrm{PaCO} 2$ in patients with COPD. Chest 2002;121:377-382.

52. Weg I, Rossoff L, Graver M, Scharf S. Development of pulmonary hypertension after lung volume reduction surgery. Am J Respir Crit Care Med 1999;159:552-556.

53. Mineo T, Pompeo E, Rogliani P, Dauri M, Turani F, Bollero P, Magliocchetti N. Effect of lung volume reduction surgery for severe emphysema on right ventricular function. Am J Respir Crit Care Med 2002;165:489-494.

54. Oswald-Mammosser M, Kessler R, Massard G, Wihlm J, Weitzenblum E, Lonsdorfer J. Effect of lung volume reduction surgery on gas exchage and pulmonary hemodynamics at rest and during exercise. Am J Respir Crit Care Med 1998;158:1020-1025.

55. Mapel DW, Dedrick D, Davis K. Trends and cardiovascular co-morbidities of COPD patients in the Veterans Administration medical system, 1991-1999. COPD 2005;2:35-41.

56. Curkendall SM, DeLuise C, Jones JK, Lanes S, Stang MR, Goehring E, She D. Cardiovascular disease in patients with chronic obstructive pulmonary disease, Saskatchewan Canada: cardiovascular disease in COPD patients. Ann Epidemiol 2006;16:63-70.

57. Sin DD, Man SF. Why are patients with chronic obstructive pulmonary disease at increased risk of cardiovascular diseases? The potential role of systemic inflammation in chronic obstructive pulmonary disease. Circulation 2003;107:1514-1519.

58. Friedman GD, Klatsky AL, Siegelaub AB. Lung function and risk of myocardial infarction and sudden cardiac death. N Engl J Med 1976; 294:1071-1075.

59. Antonelli-Incalzi R, Fuso L, De Rosa M, Forastiere F, Rapiti E, Nardecchia B, Pistelli R. Co-morbidity contributes to predict mortality of patients with chronic obstructive pulmonary disease. Eur Respir J 1997;10:2794-2800.

60. Ridker PM. Evaluating novel cardiovascular risk factors: can we better predict heart attacks? Ann Intern Med 1999;130:933-937.

61. Danesh J, Whincup P, Walker M, Lennon L, Thomson A, Appleby P, Gallimore JR, Pepys MB. Low-grade inflammation and coronary heart disease: prospective study and updated meta-analyses. BMJ 2000;321:199-204.

62. Ross R. Atherosclerosis: an inflammatory disease. N Engl J Med 1999; 340:115-126.

63. Ridker PM. Clinical application of C-reactive protein for cardiovascular disease detection and prevention. Circulation 2003;107:363-369.

64. Wedzicha JA, Seemungal TA, MacCallum PK, Paul EA, Donaldson GC, Bhowmik A, Jeffries DJ, Meade TW. Acute exacerbations of chronic obstructive pulmonary disease are accompanied by elevations 
of plasma fibrinogen and serum IL-6. Thromb Haemost 2000;84: 210-215.

65. Black S, Kushner I, Samols D. C-reactive protein. J Biol Chem 2004; 279:48487-48490.

66. Pinto-Plata VM, Mullerova H, Toso JF, Feudjo-Tepie M, Soriano JB, Vessey RS, Celli BR. C-reactive protein in patients with COPD, control smokers and non-smokers. Thorax 2006;61:23-28.

67. Broekhuizen R, Wouters EF, Creutzberg EC, Schols AM. Raised CRP levels mark metabolic and functional impairment in advanced COPD. Thorax 2006;61:17-22.

68. Dev D, Wallace E, Sankaran R, Cunniffe J, Govan JR, Wathen CG, Emmanuel FX. Value of C-reactive protein measurements in exacerbations of chronic obstructive pulmonary disease. Respir Med 1998; 92:664-667.

69. Dahl M, Vestbo J, Lange P, Bojesen SE, Tybjaerg-Hansen A, Nordestgaard BG. C-reactive protein as a predictor of prognosis in chronic obstructive pulmonary disease. Am J Respir Crit Care Med 2007;175:250-255.

70. Pearson TA, Mensah GA, Alexander RW, et al.; Centers for Disease Control and Prevention; American Heart Association. Markers of inflammation and cardiovascular disease: application to clinical and public health practice: a statement for healthcare professionals from the Centers for Disease Control and Prevention and the American Heart Association. Circulation 2003;107:499-511.

71. Ridker PM; JUPITER Study Group. Rosuvastatin in the primary prevention of cardiovascular disease among patients with low levels of low-density lipoprotein cholesterol and elevated high-sensitivity C-reactive protein: rationale and design of the JUPITER trial. Circulation 2003;108:2292-2297.

72. Ridker PM, Rifai N, Pfeffer M, Sacks F, Braunwald E. Long-term effects of pravastatin on plasma concentration of C-reactive protein. Circulation 1999;100:230-235.

73. Ridker PM, Rifai N, Lowenthal SP. Rapid reduction in C-reactive protein with cerivastatin among 785 patients with primary hypercholesterolemia. Circulation 2001;103:1191-1193.

74. Albert MA, Danielson E, Rifai N, et al. Effect of statin therapy on C-reactive protein levels: the Pravastatin Inflammation/CRP Evaluation (PRINCE): a randomized trial and cohort study. JAMA 2001;286: 64-70.

75. Soyseth V, Brekke P, Smith P, Omland T. Statin use is associated with reduced mortality in COPD. Eur Respir J 2007;2:279-283.

76. Balan KK, Critchley M. Is the dyspnea during adenosine cardiac stress test caused by bronchospasm? Am Heart J 2001;142:142-145.

77. Thurnheer R, Laube I, Kaufmann PA, Stumpe KD, Stammberger U, Bloch KE, Weder W, Russi EW. Practicability and safety of dipyridamole cardiac imaging in patients with severe chronic obstructive pulmonary disease. Eur J Nucl Med 1999;26:812-817.

78. Mathias W, Arruda A, Santos FC, Arruda AL, Mattos E, Osório A, Campos O, Gil M, Andrade JL, Carvalho AC. Safety of dobutamineatropine stress echocardiography: a prospective experience of 4,033 consecutive studies. J Am Soc Echocardiogr 1999;12:785-791.

79. Geleijnse ML, Fioretti PM, Roelandt JR. Methodology, feasibility, safety and diagnostic accuracy of dobutamine stress echocardiography. J Am Coll Cardiol 1997;30:595-606.

80. Nikolaou K, Knez A, Rist C, Wintersperger BJ, Leber A, Johnson T, Reiser MF, Becker CR. Accuracy of 64-MDCT in the diagnosis of ischemic heart disease. AJR Am J Roentgenol 2006;187:111-117.

81. Camsari A, Arikan S, Avan C, Kaya D, Pekdemir H, Ciçek D, Kiykim A, Sezer K, Akkuş N, Alkan M, et al. Metoprolol, a beta-1 selective blocker, can be used safely in coronary artery disease patients with chronic obstructive pulmonary disease. Heart Vessels 2003;18:188-192.

82. Salpeter SR, Ormiston TM, Salpeter EE. Cardioselective beta-blockers in patients with reactive airway disease: a meta-analysis. Ann Intern Med 2002;137:715-725.

83. Salpeter SR, Ormiston TM, Salpeter EE, Poole PJ, Cates CJ. Cardioselective beta-blockers for chronic obstructive pulmonary disease: a meta-analysis. Respir Med 2003;97:1094-1101.

84. Hunt SA, Abraham WT, Chin MH, et al. ACC/AHA 2005 guideline update for the diagnosis and management of chronic heart failure in the adult: a report of the American College of Cardiology/American Heart Association Task Force on Practice Guidelines (Writing Committee to Update the 2001 Guidelines for the Evaluation and Management of Heart Failure): developed in collaboration with the
American College of Chest Physicians and the International Society for Heart and Lung Transplantation: endorsed by the Heart Rhythm Society. Circulation 2005;112:e154.

85. Sirak TE, Jelic S, Le Jemtel TH. Therapeutic update: non-selective beta- and alpha-adrenergic blockade in patients with coexistent chronic obstructive pulmonary disease and chronic heart failure. J Am Coll Cardiol 2004;44:497-502.

86. George RB, Manocha K, Burford JG, Conrad SA, Kinasewitz GT. Effects of labetalol in hypertensive patients with chronic obstructive pulmonary disease. Chest 1983;83:457.

87. Krum H, Ninio D, MacDonald P. Baseline predictors of tolerability to carvedilol in patients with chronic heart failure. Heart 2000;84:615-619.

88. Kotlyar E, Keogh AM, Macdonald PS, Arnold RH, McCaffrey DJ, Glanville AR. Tolerability of carvedilol in patients with heart failure and concomitant chronic obstructive pulmonary disease or asthma. J Heart Lung Transplant 2002;21:1290-1295.

89. Salpeter S, Ormiston T, Salpeter E. Cardioselective beta-blockers for chronic obstructive pulmonary disease. Cochrane Datab System Rev 2005;4:CD003566.

90. Berger JS, Sanborn TA, Sherman W, Brown DL. Effect of chronic obstructive pulmonary disease on survival of patients with coronary heart disease having percutaneous coronary intervention. Am J Cardiol 2004;94:649-651.

91. Gao D, Grunwald GK, Rumsfeld JS, Mackenzie T, Grover FL, Perlin $\mathrm{JB}$, McDonald GO, Shroyer AL. Variation in mortality risk factors with time after coronary artery bypass graft operation. Ann Thorac Surg 2003;75:74-81.

92. Zhu YB, Xu JP, Liu ZY, Yang DN, Li XD, Li HY. Off-pump coronary artery bypass grafting versus on-pump coronary artery bypass grafting: which is better in patients with chronic obstructive pulmonary disease? J Zhejiang Univ Sci 2004;5:1005-1008.

93. Buch P, Friberg J, Scharling H, Lange P, Prescott E. Reduced lung function and the risk of atrial fibrillation in the Copenhagen City Heart Study. Eur Respir J 2003;21:1012-1016.

94. McCord J, Borzak S. Multifocal atrial tachycardia. Chest 1998;113: 203-209.

95. Kothari SA, Apiyasawat S, Asad N, Spodick DH. Evidence supporting a new rate threshold for multifocal atrial tachycardia. Clin Cardiol 2005;28:561-563.

96. Kuralay E, Cingoz F, Kiliç S, Bolcal C, Günay C, Demirkiliç U, Tatar H. Supraventricular tachyarrythmia prophylaxis after coronary artery surgery in chronic obstructive pulmonary disease patients (Early Amiodarone Prophylaxis Trial). Eur J Cardiothorac Surg 2004;25: 224-230.

97. Ueng KC, Lee SH, Wu DJ, Lin CS, Chang MS, Chen SA. Radiofrequency catheter modification of atrioventricular junction in patients with COPD and medically refractory multifocal atrial tachycardia. Chest 2000;117:52-59.

98. Salpeter S, Ormiston T, Salpeter E. Cardiovascular effects of betaagonists in patients with asthma and COPD: a meta-analysis. Chest 2004;125:2309-2321.

99. Calverley PM, Anderson JA, Celli B, Ferguson GT, Jenkins C, Jones PW, Yates JC, Vestbo J; TORCH Investigators. Salmeterol and fluticasone propionate and survival in chronic obstructive pulmonary disease. N Engl J Med 2007;356:775-789.

100. Van der Hooft CS, Heeringa J, Brusselle GG, Hofman A, Witteman JC, Kingma JH, Sturkenboom MC, Stricker BH. Corticosteroids and the risk of atrial fibrillation. Arch Intern Med 2006;166:1016-1020.

101. Huerta C, Lanes SF, Garcia Rodriguez LA. Respiratory medications and the risk of cardiac arrhythmias. Epidemiology 2005;16:360-366.

102. Fujimoto S, Kondoh H, Yamamoto Y, Hisanaga S, Tanaka K. Holter electrocardiogram monitoring in nephrotic patients during methylprednisolone pulse therapy. Am J Nephrol 1990;10:231-236.

103. Go AS, Hylek EM, Phillips KA, et al. Prevalence of diagnosed atrial fibrillation in adults: national implications for rhythm management and stroke prevention: the AnTicoagulation and Risk Factors in Atrial Fibrillation (ATRIA) Study. JAMA 2001;285:2370-2375.

104. Ozen S, Tokgozoglu L, Saatci U. Are late potentials operative in arrhythmias following methylprednisolone pulse therapy. Int J Cardiol 1992;36:234-235.

105. Freedman MD, Schocket AL, Chapel N, Gerber JG. Anaphylaxis after intravenous methylprednisolone administration. JAMA 1981;245: 607-608. 